\title{
What is the survival rate of dental implants in Turkey? A systematic review.
}

\author{
Fatih Cabbar', Muammer Çağrı Burdurlu' ${ }^{1}$, Nevzat Sezer Işiksaçan, Berkem Atalay², Gonca Duygu \\ Çapar $^{3}$
}

${ }^{1}$ Department of Oral and Maxillofacial Surgery, Faculty of Dentistry, University of Yeditepe, Bagdat cd No:238, Goztepe, Kadikoy, Istanbul, Turkey

${ }^{2}$ Department of Oral and Maxillofacial Surgery, Faculty of Dentistry, University of Istanbul, Turgut Ozal cd No:118, Fatih, Istanbul, Turkey

${ }^{3}$ Department of Oral and Maxillofacial Surgery, Faculty of Dentistry, University of Trakya, Balkan Yerleskesi, Edirne, Turkey

\begin{abstract}
Objectives: The purpose of this study was to examine the failures of dental implants in Turkey and to investigate the complications, which may lead to implant loss.

Study Design: The Systematic review was performed in accordance with PRISMA statement and Cochrane guidelines. PubMed, Google Scholar, Cochrane Library, TUBITAK ULAKBIM databases were searched for both in English and Turkish up to 2015. Data on implant failure, demographic variables and outcomes were included. Nonclinical and animal reports were excluded. Search was conducted by two authors and conflicts were resolved by a third reader.

Results: Seventeen reports were satisfied the inclusion criteria. In total, $1764(51.19 \%$ female and 48.81\% male) participants were included. A total of 4487 implants were used. Total implant success was $97.48 \%$ ( 61 early and 52 late failures) in a follow-up period for $42.71 \pm 33.78$ months. The failure reasons were infection $(38.9 \%)$, lack of osseointegration $(\mathbf{4 4 . 4 \% )}$ ), implant fractures $(5.8 \%)$, periimplantitis $(1.76 \%)$, sensory disturbances $(2.65 \%)$.

Conclusion: Immediate and late implantation has similar failure rates and failure rates may increase with time. Implants have similar survival rates with the literature in Turkey region as well. It was observed that few reports with limited data were reported considering the high number of implants placed in the Turkey.
\end{abstract}

Keywords: Dental implant, Failure rates, Systematic review

Accepted on November 04, 2017

\section{Introduction}

Oral rehabilitation with dental implants is a well-documented procedure. Since osseointegration was first described by Branemark et al. [1], dental implants are being used with all kinds of prosthesis as well as a maxillofacial prosthesis. In later years treatment with dental implants has been examined in many long-term clinical studies, focusing primarily on implant survival [2-4]. The current literature shows high implant success rates ranging from $90 \%$ to $97 \%$ [5]. However, the terms survival and success are generating confusions and used incorrectly even in many academic studies [4]. There are many studies on success and survival rates of implants because of the large number of variables, such as surgical techniques, prosthetic variations, materials used, patient-related factors and follow-up periods. In addition, there were different protocols and criteria reported for the definition of implant success and survival, and there is no consensus or international standardization [3,6-11].

Despite the high success or survival rates, failures may occur [3]. Failure is determined when the performance of a dental implant falls below a particular level [12]. Dental implant failures may originate from different epidemiological causes and can be biological, mechanical, iatrogenic or due to insufficient patient adaptation. Failures are classified as early and late failures. If the failure occurs before osseointegration and at the time of the abutment connection, it is considered as an early failure; if it occurs after osseointegration, during occlusal loading, then it is regarded as a late failure [12-14]. There were different causes of failures reported for early and late implant failures. While early failures were mostly related to lack of osseointegration caused by soft tissue involvement between implant and bone, infection, different kinds of traumas, delayed healing or insufficient osseointegration 
period and insufficient keratinized gingival width, the late failures are a result of breakdown of osseointegration by reasons such as, trauma, restorative principles, infection or mechanical complications [14-17].

Dental implants are being used for more than 20 years in the Turkey Republic. The assumed dental implant placement is about 350,000 annually, which is about $4 \%$ of the total population, and it is increasing [18]. However, there isn't any review, which examines the failure rates of implants, exist for this region. The purpose of this study is to examine failure rates of dental implants in Turkey and to investigate the complications, which may lead to implant loss.

\section{Methods}

This systematic review was performed in accordance with the PRISMA statement (Preferred Reporting Items for Systematic Review and Meta-analyses) [19] and Cochrane guidelines. The clinical questions were divided and categorized according to the PICO strategy (Participant, Intervention, Comparison, and Outcome) (Table 1).

Table 1. PICOS (Participants, Interventions, Comparisons, Outcomes, Study Design).

\begin{tabular}{ll}
\hline Participants & $\begin{array}{l}\text { Generally healthy patients with total or partially } \\
\text { edentulous dental arches }\end{array}$ \\
\hline Interventions & $\begin{array}{l}\text { Dental implants, single or multiple implants, implant } \\
\text { supported prosthesis }\end{array}$ \\
\hline Comparison Outcomes & $\begin{array}{l}\text { Cumulative survival of dental implants, incidence of } \\
\text { implant-related complications }\end{array}$ \\
\hline Study Design & $\begin{array}{l}\text { Randomized controlled trial, prospective cohort study, } \\
\text { retrospective cohort study. }\end{array}$ \\
\hline $\begin{array}{l}\text { Language: English and Turkish; The primary objective of the study is to evaluate } \\
\text { the survival and failure rates of dental implants in Turkey. }\end{array}$ \\
\hline
\end{tabular}

\section{Objectives}

The research question was 'What is the survival rate of dental implants in Turkey?' The main objective of this review was to fill the gap in the literature related to the clinical applications of dental implants and their common complications in Turkey region. This data would be useful for both clinicians and academicians for further studies and making decisions in treatment modalities.

\section{Search Strategy}

PubMed/MEDLINE, Google Scholar, Cochrane Library and TUBITAK ULAKBIM DergiPark databases were searched for relevant articles published in Both English and Turkish with no date restriction up to 2015 with the keywords Dental Implant, Failure, Survival, Success, Turkey and Turkish in different combinations.

The inclusion criteria were; papers in English or Turkish, published in peer review journals, which reported dental implant failures. The articles related to human subjects. For this review, the implant failure was regarded as the total loss of the dental implant.

The exclusion criteria were: papers written in other languages, animal studies, in vitro studies, implants performed with maxillary sinus floor augmentation procedures, distraction osteogenesis, bone blocks or implants performed with bone grafts, non-oral implants and case reports and reviews.

The literature search was conducted by two independent authors (FC and MCB). The abstracts were first analysed. The papers were extracted according to the exclusion criteria from abstracts and full-text articles. All duplicates were removed. Two authors independently judged articles and collect the data before a decision was made and conflicts, if any was resolved by analyses of a third reader (GDC).

From each paper included, relevant demographic and outcome data were extracted such as year of publication, the number of patients, gender, mean patient age, the number of implants performed, mean follow-up, surgical procedure, and outcomes, type of implant loading, the number of implant failures, failure times and reasons. The failure of the implant regarded as the total loss of the implant.

\section{Quality Analysis}

For increasing the reliability and to evaluate the risk of bias, the analyses of quality of the included studies were done, as in the study conducted by Moraschini et al. [4]. The methodology used was proposed by Nguyen et al. [20] combined with Needleman guide [21] and the Cochrane recommendations [22]. Table 2 shows the criteria assessed with their potential scores. When these scores added together, they generate a maximum score of 16 points. A score of $>12$ was regarded as low, a score between 10 and 12 was regarded as moderate and $<10$ was regarded as high.

Table 2. Criteria for quality analyses.

\begin{tabular}{ll}
\hline Criteria & $\begin{array}{l}\text { Maximum } \\
\text { score }\end{array}$ \\
\hline Sample size & 2 \\
\hline Studies with samples $<100$ participants $=1$ & 2 \\
\hline Studies with samples $\geq 100$ participants=2 & 2 \\
\hline Follow-up time & \\
\hline Studies without a period of follow-up=1 & \\
\hline Selection criteria & \\
\hline Selection criteria not mentioned or poorly defined $=1$ & \\
\hline Selection criteria well defined=2 & \\
\hline Description of population &
\end{tabular}




\begin{tabular}{l} 
Available statistical methods \\
$\begin{array}{l}\text { Studies that did not make available the statistical methods } \\
\text { used }=0\end{array}$ \\
$\begin{array}{l}\text { Studies that made available the statistical method used, but did } \\
\text { not describe them clearly }=1\end{array}$ \\
$\begin{array}{l}\text { Studies that made available the statistical method used, and } \\
\text { described them clearly=2 }\end{array}$ \\
\hline Criteria of success \\
\hline $\begin{array}{l}\text { Studies that used a scale of success for evaluation of implants } \\
\text { and described it=1 }\end{array}$ \\
\hline Description of objectives \\
\hline Objective of study undefined $=1$ \\
\hline Objective of study clearly defined $=2$ \\
\hline Randomized study \\
\hline Randomized clinical trials (RCT) \\
\hline Number of implants evaluated \\
\hline Studies with samples $<100$ implants $=1$ \\
\hline Studies with samples $\geq 100$ implants $=2$ \\
\hline Conclusions \\
\hline If the conclusions are in accordance with the objective of the \\
study
\end{tabular}

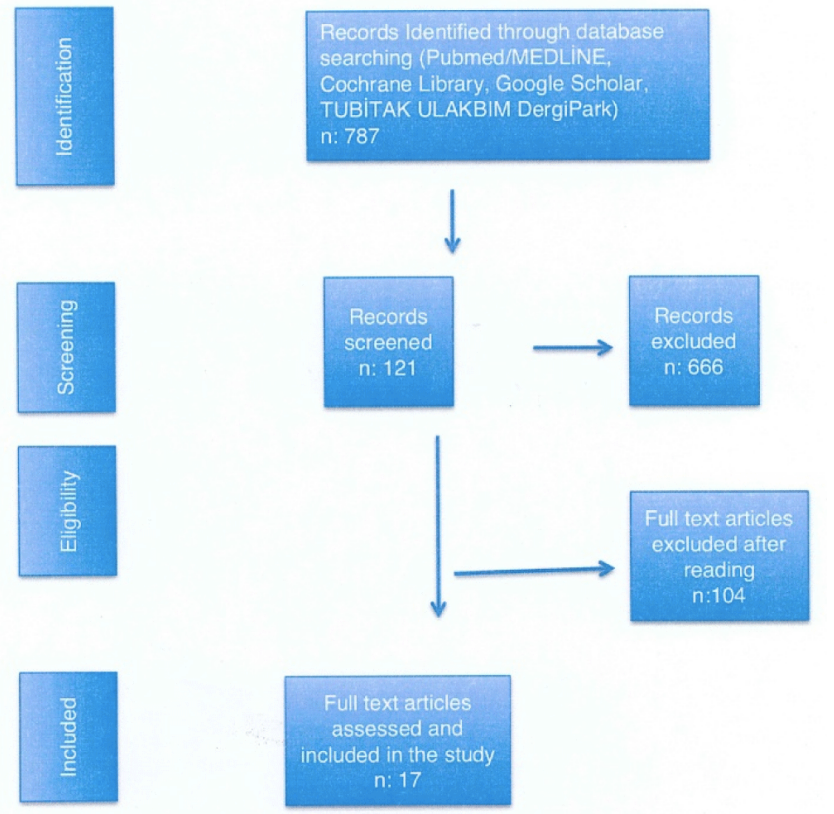

Figure 1. Search strategy and screening process.

\section{Statistical Analyses}

After evaluation of the included articles, considerable heterogeneity was present in the study designs, therefore it was not possible to perform reliable meta-analyses. Because of this, descriptive type of methods such as; mean, standard deviation, frequency, percent, and distribution, were used. The statistical analyses performed by NCSS (Number Cruncher Statistical System) 2007 Statistical software (Utah, USA) program.

\section{Results}

The initial search yielded 454 titles in Medline/Pubmed, Cochrane Library and Google Scholar and 333 titles in TUBITAK ULAKBIM DergiPark. After the initial evaluation, 121 papers were selected. After careful reading 104 articles were excluded and remaining 17 articles were included in this review [3,11,23-37]. The included studies were published between 2003 and 2015. The process for study selection and screening and the reasons for exclusion are shown in Figure 1.

A total of 17 papers reported the implant failure were included in this review. Details of the studies were listed in Table $3 \mathrm{a}$ and 3b. The mean follow-up time was $42.71 \pm 33.78$ months (Min: 12, Max: 120). Eleven prospective studies and 6 retrospective studies were included. The studies included 1764 patients with a mean age of $46.78 \pm 7.39$ years (between 18 and 80 years). Of these patients $903(51.19 \%)$ were female and 725 were male $(48.81 \%)$.

Table 3a. Demographic data and the analyses of implant failure included in 17 articles.

\begin{tabular}{ll}
\hline 17 articles; Number of total patients & 1764 \\
\hline Female & $903(51.19 \%)$ \\
\hline Male & $725(48.81 \%)$ \\
\hline Mean age & $46.78 \pm 7.39($ Min: 18; Max: 80$)$ \\
\hline Number of implants & 4487 \\
\hline Maxilla & $2074(46.22 \%)$ \\
\hline Mandible & $2455(53.78 \%)$ \\
\hline Follow-up & $42.71 \pm 33.78($ Min: $12 ;$ Max: 120$)$ \\
\hline Implant fracture & $4(0.09 \%)$ \\
\hline Early implant failure & $61(53.98 \%)$ \\
\hline Late implant failure & $52(46.02 \%)$ \\
\hline Total implant failure & $113(2.52 \%)$ \\
\hline Survival rate & $97.48 \%$ \\
\hline
\end{tabular}

Table 3b. Details of the studies included in this review. F: Female; M: Male; NR: Not Reported.

\begin{tabular}{|c|c|c|c|c|c|c|c|c|c|c|c|c|}
\hline Author Year & $\begin{array}{l}\text { Study Design \& } \\
\text { Follow-up time }\end{array}$ & $\begin{array}{l}\text { No. } \\
\text { Participants } \\
\text { Gender }\end{array}$ & $\begin{array}{l}\text { Of } \\
\&\end{array}$ & $\begin{array}{l}\text { Age range } \\
\text { Mean Age }\end{array}$ & $\begin{array}{l}\text { Number } \\
\text { implants } \\
\text { implant } \\
\text { system }\end{array}$ & $\begin{array}{l}\text { of } \\
\&\end{array}$ & $\begin{array}{l}\text { Place of } \\
\text { implantation }\end{array}$ & $\begin{array}{l}\text { Healing } \\
\text { period } \\
\text { for } \\
\text { loading } \\
\text { (months) }\end{array}$ & $\begin{array}{l}\text { Timing of } \\
\text { implantation }\end{array}$ & Early failure & Late failure & $\begin{array}{l}\text { Place of } \\
\text { Failure }\end{array}$ \\
\hline
\end{tabular}




\begin{tabular}{|c|c|c|c|c|c|c|c|c|c|c|c|}
\hline $\begin{array}{l}\text { Ozkan et al. } \\
2007\end{array}$ & $\begin{array}{l}\text { Prospective } \\
\text { Cohort } 3 \text { years }\end{array}$ & $63(25 \mathrm{M} / 38 \mathrm{~F})$ & $\begin{array}{l}18-6346,9 \\
46 \pm 9\end{array}$ & $\begin{array}{l}203 \quad(105 \\
\text { Straumann, } \\
53 \text { Camlog, } \\
45 \text { Frialit })\end{array}$ & $\begin{array}{l}\text { Maxilla } 9 \\
\text { Mandible } \\
112\end{array}$ & 91 & $\begin{array}{l}\text { Mandible } \\
3, \\
\text { Maxilla } 6\end{array}$ & $\begin{array}{l}\text { Late } \\
\text { implantation }\end{array}$ & $\begin{array}{l}1 \text { Straumann } \\
\text { implant, } \\
\text { Female patient } \\
\text { (infection) }\end{array}$ & & NR \\
\hline $\begin{array}{l}\text { Gulsahi et } \\
\text { al. } 2007\end{array}$ & $\begin{array}{l}\text { Prospective } \\
\text { Cohort } \\
\text { month }\end{array}$ & $14(5 \mathrm{M} / 9 \mathrm{~F})$ & $23-5941,1$ & 28 (Frialit) & $\begin{array}{l}\text { Maxilla } 2 \\
\text { Mandible } 0\end{array}$ & $0^{28}$ & 6 & $\begin{array}{l}\text { Late } \\
\text { implantation }\end{array}$ & $\begin{array}{l}5 \quad \text { Frialite } \\
\text { implant (lack of } \\
\text { Osseointegrati } \\
\text { on) }\end{array}$ & & $\begin{array}{l}5 \\
\text { Maxilla }\end{array}$ \\
\hline $\begin{array}{l}\text { Soydan et } \\
\text { al. } 2013\end{array}$ & $\begin{array}{l}\text { Prospective } \\
\text { Cohort, } 51,6 \\
\text { months early } \\
\text { implantation, } \\
61,9-\text {-month } \\
\text { immediate } \\
\text { implantation }\end{array}$ & $36(16 \mathrm{M} / 20 \mathrm{~F})$ & $\begin{array}{l}\text { NR } 55,7 \pm \\
28,5\end{array}$ & $\begin{array}{l}50 \\
\text { (Straumann) }\end{array}$ & $\begin{array}{l}\text { Maxilla } \\
\text { Mandible } 17\end{array}$ & $\begin{array}{l}33 \\
17\end{array}$ & $\begin{array}{l}\text { Mandibul } \\
\text { a 2, } \\
\text { Maksilla } \\
4\end{array}$ & $\begin{array}{l}26 \\
\text { immediate } \\
\text { implantation } \\
\text { s, } 24 \text { one } \\
\text { month after } \\
\text { extraction }\end{array}$ & & 1 Straumann implant & NR \\
\hline $\begin{array}{l}\text { Simsek et. } \\
\text { Al. } 2003\end{array}$ & $\begin{array}{l}\text { Prospective } \\
\text { Cohort } \\
\text { months }\end{array}$ & 20 (NR) & NR & 70 (NR) & NR & & NR & $\begin{array}{l}\text { Immediate } \\
\text { implantation }\end{array}$ & $\begin{array}{l}6 \text { implants (4 } \\
\text { had previous } \\
\text { periodontitis, } 2 \\
\text { had periapical } \\
\text { infection }\end{array}$ & & $\begin{array}{l}4 \\
\text { Maxilla, } \\
2 \\
\text { Mandibl } \\
\text { e }\end{array}$ \\
\hline $\begin{array}{l}\text { Akın et al. } \\
2009\end{array}$ & $\begin{array}{l}\text { Prospective } \\
\text { Cohort } 24 \\
\text { months }\end{array}$ & $32(14 \mathrm{M} / 18 \mathrm{~F})$ & $19-62 \mathrm{NR}$ & $\begin{array}{l}106 \quad(29 \\
\text { Straumann, } \\
+7 \text { Miss, } \quad ! 8 \\
\text { Biolok, } \quad 12 \\
\text { Biotech) }\end{array}$ & NR & & NR & $\begin{array}{l}\text { Late } \\
\text { implantation }\end{array}$ & & $\begin{array}{l}1 \quad \text { implant neck } \\
\text { fracture }\end{array}$ & NR \\
\hline $\begin{array}{l}\text { Eltas et al. } \\
2013\end{array}$ & $\begin{array}{l}\text { Prospective } \\
\text { Cohort } \\
\text { months }\end{array}$ & $79(34 \mathrm{M} / 45 \mathrm{~F})$ & $\begin{array}{l}20-78 \\
45,19\end{array}$ & $\begin{array}{l}193 \\
\text { (Straumann, } \\
\text { Xive) }\end{array}$ & $\begin{array}{l}\text { Maxilla } 8 \\
\text { Mandible } \\
106\end{array}$ & 87 & $\begin{array}{l}\text { Mandibul } \\
\text { a } 3, \\
\text { Maxilla } 6\end{array}$ & $\begin{array}{l}\text { Late } \\
\text { implantation }\end{array}$ & $\begin{array}{lr}5 & \text { implant } \\
\text { (periimplantitis) }\end{array}$ & $\begin{array}{l}1 \quad \text { implant neck } \\
\text { fracture (16 months } \\
\text { later) }\end{array}$ & NR \\
\hline $\begin{array}{l}\text { Celebi et al. } \\
2012\end{array}$ & $\begin{array}{l}\text { Retrospective } \\
\text { Cohort } 24 \\
\text { months }\end{array}$ & $168(72 \mathrm{M} / 96 \mathrm{~F})$ & $18-8044$ & $\begin{array}{l}549 \\
\text { (Straumann) }\end{array}$ & $\begin{array}{l}\text { Maxilla } 27 \\
\text { Mandible } \\
278\end{array}$ & 271 & NR & $\begin{array}{l}542 \quad \text { Late } \\
\text { implantation } \\
\text {, } 8 \\
\text { immediate } \\
\text { implantation }\end{array}$ & $\begin{array}{l}2 \quad \text { Straumann } \\
\text { implant (1 } \\
\text { performed in } \\
\text { extraction } \\
\text { socket which } \\
\text { implant threads } \\
\text { were exposed, } \\
1 \text { performed by } \\
\text { internal sinus } \\
\text { lifting) }\end{array}$ & 1 strauman implant & NR \\
\hline $\begin{array}{l}\text { Bolukbası } \\
\text { et al. } 2013\end{array}$ & $\begin{array}{l}\text { Prospective } \\
\text { Cohort } \\
\text { months }\end{array}$ & $150(93 \mathrm{M} / 57 \mathrm{~F})$ & $\begin{array}{lr}29.03 & \pm \\
5,47 & 33,98 \\
\pm & 4,57 \\
34,48 & \pm \\
5,58 & (3 \\
\text { groups }) & \end{array}$ & 403 (NR) & NR & & NR & $\begin{array}{l}\text { Late } \\
\text { implantation }\end{array}$ & $\begin{array}{l}3 \\
\text { failure }\end{array}$ & 2 implant failure & NR \\
\hline $\begin{array}{l}\text { Bilhan et al. } \\
2012\end{array}$ & $\begin{array}{l}\text { Retrospective } \\
\text { Cohort } 24 \\
\text { months }\end{array}$ & $89(36 \mathrm{M} / 53 \mathrm{~F})$ & $\begin{array}{l}59,63 \quad \pm \\
9,62,54,97 \\
\pm 12,24(2 \\
\text { groups) }\end{array}$ & $\begin{array}{l}278 \quad(126 \\
\text { Astra Tech, } \\
71 \\
\text { Straumann, } \\
\text { 51 Biolok, } 30 \\
\text { Zimmer) }\end{array}$ & NR & & NR & $\begin{array}{l}\text { Late } \\
\text { implantation }\end{array}$ & $\begin{array}{l}6 \\
\text { failure implant }\end{array}$ & 3 implant failure & $\begin{array}{l}6 \\
\text { Maxilla, } \\
3 \\
\text { Mandibl } \\
\text { e }\end{array}$ \\
\hline $\begin{array}{l}\text { Piskin et al. } \\
2010\end{array}$ & $\begin{array}{lr}\text { Retrospective } \\
\text { Cohort, } & \text { Multi } \\
\text { centered, } & 4 \\
\text { years } & \end{array}$ & 116 (NR) & NR & 204 (NR) & $\begin{array}{l}\text { Maxilla } 9 \\
\text { Mandible } \\
107\end{array}$ & 97 & NR & $\begin{array}{l}\text { Late } \\
\text { implantation }\end{array}$ & & $\begin{array}{l}1 \text { implant fracture ( } 2 \\
\text { years) }\end{array}$ & NR \\
\hline $\begin{array}{l}\text { Bilhan et al. } \\
2011\end{array}$ & $\begin{array}{l}\text { Retrospective } \\
\text { Cohort, } 3 \text { years }\end{array}$ & $117(45 \mathrm{M} / 72 \mathrm{~F})$ & NR 46,94 & $\begin{array}{l}165 \quad(31 \\
\text { Astra Tech, } \\
79 \\
\text { Straumann, } \\
\text { 34 Biolok, } 21 \\
\text { Xive) }\end{array}$ & $\begin{array}{lr}\text { Maxilla } & 8 \\
\text { Mandible } 77\end{array}$ & $\begin{array}{l}88 \\
77\end{array}$ & $4-06$ & $\begin{array}{l}\text { İmmediate } \\
\text { implantaiton }\end{array}$ & $\begin{array}{l}9 \\
\text { failure }\end{array}$ & 1 implant failure & $\begin{array}{l}3 \\
\text { mandibl } \\
\mathrm{e}, \quad 7 \\
\text { maxilla }\end{array}$ \\
\hline $\begin{array}{l}\text { Atalay et al. } \\
2013\end{array}$ & $\begin{array}{l}\text { Retrospective } \\
\text { Cohort, } 5 \text { years }\end{array}$ & $72(28 \mathrm{M} / 44 \mathrm{~F})$ & 22-74 NR & 110 (NR) & $\begin{array}{l}\text { Maxilla } 6 \\
\text { Mandible } 50\end{array}$ & $\begin{array}{c}60 \\
50\end{array}$ & 3 & $\begin{array}{l}\text { immediate } \\
\text { implantation }\end{array}$ & $\begin{array}{l}4 \quad \text { implant } \\
\text { failure }\end{array}$ & $\begin{array}{l}1 \text { implant failure } \\
\text { (periimplantitis) }\end{array}$ & NR \\
\hline $\begin{array}{l}\text { Güncü et al. } \\
2008\end{array}$ & $\begin{array}{l}\text { Prospective } \\
\text { Cohort, } \\
\text { months }\end{array}$ & $12(4 \mathrm{M} / 8 \mathrm{~F})$ & $\begin{array}{l}30-55 \\
41,09 \\
8,46\end{array}$ & $\begin{array}{l}24 \\
\text { (Branemark) }\end{array}$ & $\begin{array}{l}\text { Maxilla } \\
\text { Mandible } 24\end{array}$ & 24 & $0-3$ & $\begin{array}{l}\text { Late } \\
\text { implantation } \\
\text {. }\end{array}$ & $\begin{array}{l}1 \\
\text { loading) }\end{array}$ & & $\begin{array}{l}1 \\
\text { Mandibl } \\
\mathrm{e}\end{array}$ \\
\hline
\end{tabular}




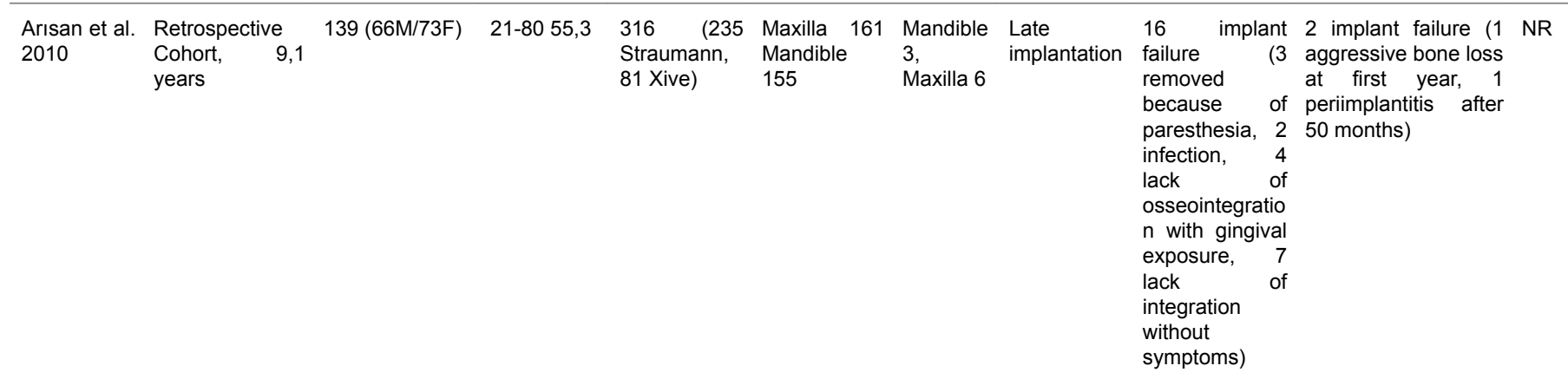

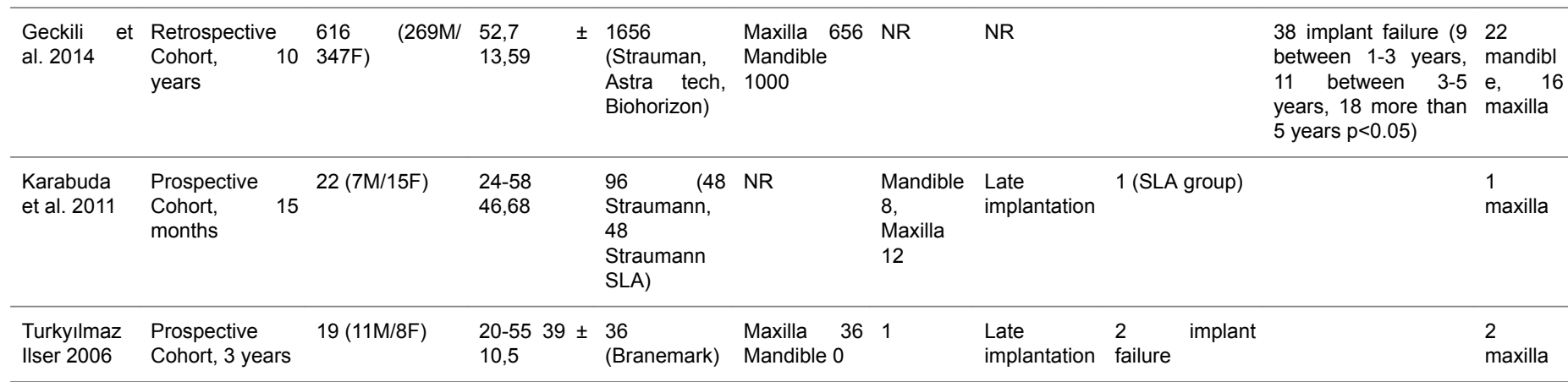

A total of 4487 dental implants were performed in these patients. There were 9 different commercial brands of implants used: ITI, (Straumann AG, Waldenburg, Switzerland), Astra Tech (Astra Tech AB, Mölndal, Sweden), Biolock (Biolock International Inc, Deerfield Beach, Fla), Brånemark System (Nobel Biocare AB, Göteborg, Sweden), Frialit (Friatecü Mannheim, Germany), Mis (Mis Implant Tech, Savion Israel), Zimmer (Carlsbad, CA, USA), Biohorizon (Biohorizon, Birmingham, AL, USA), Xive (Dentsply Friadent, Mannheim, Germany). Of these implants performed, 2074 (\%46.22) were in the maxilla and $2413(\% 53.78)$ were in the mandible.

\section{Quality Assessment}

The scoring of the articles for assessing the potential risk of bias was shown in Table 4. As a result of quality analyses, 8 studies were classified as having a low risk of bias $[3,23,30-36], \quad 8$ studies were classified as moderate [11,24-29,33,37] and only 1 study was classified as having a high bias risk [25]. Due to having a brief explanation about implant failure, the only study having a high risk of bias was not excluded from the study.

Table 4. Quality analyses of the studies included in this review.

\begin{tabular}{|c|c|c|c|c|c|c|c|c|c|c|c|c|}
\hline Author & $\begin{array}{l}\text { Sample } \\
\text { Size }\end{array}$ & $\begin{array}{l}\text { Follow- } \\
\text { up }\end{array}$ & $\begin{array}{l}\text { Selection } \\
\text { criteria }\end{array}$ & $\begin{array}{l}\text { Description } \\
\text { of population }\end{array}$ & $\begin{array}{l}\text { Statistical } \\
\text { methods } \\
\text { described }\end{array}$ & $\begin{array}{l}\text { Criteria } \\
\text { of } \\
\text { success }\end{array}$ & $\begin{array}{l}\text { Descriptive } \\
\text { of objectives }\end{array}$ & $\begin{array}{l}\text { Randomized } \\
\text { study }\end{array}$ & $\begin{array}{l}\text { Implant } \\
\text { number }\end{array}$ & Conclusions & Total & $\begin{array}{l}\text { Bias } \\
\text { Potential }\end{array}$ \\
\hline Ozkan et al. & 1 & 2 & 2 & 1 & 2 & 0 & 2 & 0 & 2 & 1 & 13 & Low \\
\hline Gulsahi et al. & 1 & 2 & 2 & 1 & 2 & 0 & 2 & 0 & 1 & 1 & 12 & Moderate \\
\hline Soydan et al. & 1 & 2 & 2 & 1 & 2 & 1 & 2 & 0 & 1 & 1 & 12 & Moderate \\
\hline Simsek et al. & 1 & 0 & 2 & 0 & 2 & 0 & 2 & 0 & 1 & 1 & 9 & High \\
\hline Akın et al. & 1 & 2 & 1 & 1 & 0 & 0 & 2 & 0 & 2 & 1 & 10 & Moderate \\
\hline Eltas et al. 2012 & 1 & 2 & 1 & 1 & 0 & 1 & 2 & 0 & 2 & 1 & 11 & Moderate \\
\hline Celebi et al. & 2 & 2 & 0 & 1 & 0 & 0 & 2 & 0 & 2 & 1 & 10 & Moderate \\
\hline Bolukbası et al. & 2 & 2 & 2 & 1 & 2 & 0 & 2 & 0 & 2 & 1 & 12 & Moderate \\
\hline Bilhan et al. & 1 & 2 & 2 & 1 & 2 & 0 & 2 & 0 & 2 & 1 & 13 & Low \\
\hline Piskin et al. & 2 & 2 & 2 & 0 & 2 & 0 & 2 & 0 & 2 & 1 & 13 & Low \\
\hline Bilhan et al. & 2 & 2 & 2 & 1 & 2 & 1 & 2 & 0 & 2 & 1 & 15 & Low \\
\hline Atalay et al. & 1 & 2 & 2 & 1 & 0 & 1 & 1 & 0 & 2 & 0 & 10 & Moderate \\
\hline
\end{tabular}




\begin{tabular}{|c|c|c|c|c|c|c|c|c|c|c|c|c|}
\hline Güncü et al. & 1 & 2 & 2 & 1 & 2 & 1 & 2 & 0 & 1 & 1 & 13 & Low \\
\hline Arısan et al. & 2 & 2 & 2 & 1 & 2 & 1 & 2 & 0 & 2 & 1 & 15 & Low \\
\hline Geckili et al. & 2 & 2 & 2 & 0 & 2 & 1 & 2 & 0 & 2 & 1 & 14 & Low \\
\hline Karabuda et al. & 1 & 2 & 2 & 1 & 2 & 1 & 2 & 0 & 1 & 1 & 13 & Low \\
\hline Turkyılmaz Ilser. & 1 & 2 & 2 & 1 & 0 & 1 & 2 & 0 & 1 & 1 & 11 & Moderate \\
\hline
\end{tabular}

\section{Evaluation of Implant Failures}

In eleven of these studies [23-31,34-37], implants placed in healed sockets according to standard principles [38]. In 3 articles implants were placed immediately [25,32,33]. In a study implants were placed both immediately and in healed sockets [28]. In one study implants were placed both immediately and 1 month after extraction [11]. One study did not report any implantation time [3].

Eleven of the articles included in this study used several criteria of success such as Albrektson et al. [8], Misch et al. [7], Zarb and Albrektsson [9]. The remaining others just evaluated the total loss of the implant. All 17 studies reported implant failures. The mean percentage of implant failure was $2.52 \%$ (113 implants), which shows a total survival rate of $97.48 \%$ (4374). Of these failures, $52(46.02 \%)$ were lost after loading (late failure), whereas 61 (53.98\%) were lost before loading (early failure). Three failed implants of the late-failure group were placed immediately, whereas 11 of the implants were placed in healed sockets. Twenty of the failed implants, in early failure group, were placed immediately, whereas 40 were placed in healed sockets. The other studies didn't report the implantation time for the failed implants. Distribution of the failed implants according to the jaws were; 41 maxillae and 31 mandibles, which makes a total of 72 implants. The other studies didn't report any information for the remaining 41 failures. In the early failure group, the reasons for the failure of 25 of implants were not reported. The mentioned findings for implant failures in early failure group were, 14 infections (6 had the previous infection such as periodontitis and periapical infection), 16 lack of osseointegration (7 had no symptoms), 1 bone perforation during surgery, 1 implant placement with sinus lifting, 1 early loading, and 3 paresthesia (in 2 patients, both recovered at the end of 1 year). In the late-failure group, 45 of the implants' failure reason was not reported. The findings reported in the late failure group were, 1 implant body fracture, 1 immediate loading, 2 implant neck fracture, 2 periimplantitis and 1 aggressive bone loss without infection.

\section{Discussion}

The aim of this systematic review was to evaluate the survival and failure rates of dental implants in Turkey by means of investigating studies reported data on this subject. Regarding the methodology of this review, following inclusion/exclusion criteria and quality analyses, 770 papers were excluded. Randomized controlled trials are regarded as one of the most reliable studies for clinical practice. Therefore, the most preferred study design for systematic reviews is randomized controlled trials [39]. Unfortunately, there wasn't any randomized controlled trial that met the criteria of inclusion. Remaining articles included in this systematic review were retrospective and prospective studies. The absence of randomized controlled trials may increase the risk of bias. Therefore, quality analysis was done for included studies. Only one study had a high risk of bias [25]. However, it was reported that narrowing the inclusion criteria increases the homogeneity of the data [40]. Regarding the brief data about implant failure of that study, authors decided to include it in the present review considering inclusion criteria.

The present review showed a mean failure rate of $2.52 \%$, which leads to $97.48 \%$ survival rate, for a total number of 4487 dental implants in 17 studies, with a follow-up period of 42.71 \pm 33.78 months. Although it is still under debate, for proper analyses of the survival rate of implants, at least 5 years of follow-up is mandatory [41-43]. There were 3 studies which had a follow-up period longer than 5 years in this review. In those studies, the survival rates were $95.45 \%$ with immediate implantation for a follow-up for 5 years [33], 94.3\% with late implantation for a follow-up for 9.1 years [35], and $93.8 \%$ for a follow-up for 10 years (the implantation time was not reported) [3]. In a systematic review conducted by Moraschini et al., a mean survival rate of $91.2 \%$ was reported for studies longer than 20 years [4]. In two other reviews, implant survival rates were reported $97.5 \%$ up to 5 years [39] and $96.5 \%$ for 1583 implant for a follow-up of 5 years [44]. Regarding this data Moraschini et al. suggested that survival rates of implants are decreasing over time [4]. However, another meta-analysis, which studied effects of smoking on success of implants, suggested that the rate of implant failure does not increase with time [45] In the present review, the survival rate of studies with a follow-up shorter than 5 years was $97.83 \%$, which is higher than studies with a follow-up period longer than 5 years. This finding is in line with the previous review that there might be a slight decrease in the survival rates of dental implants over time [4].

There were controversial findings reported in the literature about the incidence of early and late failures. In a 19 years follow-up retrospective study conducted by Han. et al., a higher number of early failures were observed $(57.3 \%)$ than late failures, which is supported by other studies $[14,46,47]$. However, opposite findings were also reported $[17,48]$. These different findings between studies can be related to different variables, including implant systems, the level of experience, and patient characteristics [14,49,50]. Approximately 113 $(2.52 \%)$ implant failures were observed in this review for a 
total of 4487 implants. Of these failures, 61 (53.98\%) occurred before loading, while $52(46.02 \%)$ were late failures and occurred after loading. Therefore, a higher number of implants were lost before loading in this review. It should be noted that there were only 3 studies had a follow-up period more than 5 year in this review, and that 41 of the implants in late failure group were observed in those studies [3,33,35]. In addition, 38 of the late failures were seen only in one study with a followup of 10 years and 18 of those implants were lost in more than 5 years [3], which may be supporting that late failure rate increases with time.

It was reported that the most common causes of early implant failures were bone necrosis due to overheating, bacterial contamination, insufficient bone quality, micro-movement of the implant and early loading [51]. Twenty-five of the implants in early failure group had no failure reason reported, but 14 (38.9\%) of the remaining 36 implants were lost because of infection. Possible reasons of infection were reported to be inaccurate flap design, overheating, and placement of an implant in an infected socket [52]. Of the failed implants, 6 had the previous infection before implantation, such as periodontitis and periapical lesion.

Failure due to lack of osseointegration was observed for 16 $(44.4 \%)$ implants. In one of these studies, it was reported that lack of osseointegration was more common in the maxilla, but this result was not statistically significant [35]. In the other study, which reported 5 implant failures due to lack of osseointegration, the failures were also maxillary implants [24]. It is known that poor bone quality may lead to a lack of osseointegration and the cortical structure of the maxilla is lower [15], which might be the reason for these failures.

Lundgren et al. suggested that early loading may lead to insufficient osseointegration [53]. Micromotion caused by occlusal forces may cause fibrous tissue formation between bone and implant. However, recent studies have indicated that immediate or early loading protocols can be used successfully $[34,54]$. In the present review, there was only 1 implant failure correlated to immediate loading, but in that study, the author indicated that immediate functioning of the implant had no negative effect on dental implant stability [34].

Sensory complications are mostly related to poor clinical handling. In a systematic review conducted by Berglundh et al., most of the included studies had reported an incidence of $1-2 \%$ sensory disturbances. In two studies sensory complications occurred $6.9 \%$ and $19 \%$ [39]. However, most of the sensory disturbances dissolve within 1 year. There were few papers concerned about sensory complications persisting more than 1 year $[55,56]$. In the present review, 1 study reported postoperative pain and paresthesia for 3 implants in 2 patients [35]. The incidence of implant failure because of sensory disturbance was $2.65 \%$ in all 113 implant failures and $0.11 \%$ patients in all 1764 patients. The authors reported that after removing the implants the sensory disturbance had recovered within 1 year [35].
There wasn't any reported reason for the 45 of the implants in the late-failure group. It was reported that periimplantitis and overloading are the most common causes of late implant failures [14,57,58]. Recent studies diagnosed overloading by the presence of parafunction, mechanical complications such as screw fracture or loosening, implant or prosthesis fracture [14]. The studies included in this review reported 2 implant neck fractures and 1 implant fracture as a reason for late failures, which was the $5.8 \%$ of total late failures. Implant failure caused by implant fracture is remarkably low in the literature $[14,59,60]$. But Takeshita et al. reported the fracture incidence of $7.4 \%$, and Chappuis et al. reported $3.2 \%$, similar to this review [61,62]. Berglundh et al. indicated that it is not a common complication and its incidence is $<1 \%$ for a period of 5 years. Authors suggested that the proportion of implant failure because of implant fracture in total implant failure was between $5-20 \%$, which is in concordance with the present review [39]. There are possible reasons reported for implant fractures, which include inadequate design or adjustment of the prosthesis, implant size, heavy occlusal loading, metal fatigue, aggressive bone loss and galvanic activity increase over time $[14,59,60]$.

Peri-implantitis was evaluated by inflammatory parameters by using assessments on probing depth, suppuration, plaque index and bleeding on probing. It is mostly caused by poor oral hygiene, poor clinical handling, lack of keratinized gingiva and design of prosthesis $[15,49,63,64]$. There were only two periimplantitis cases reported for late implant failure. But it should be noted that 45 of the late failures reported no possible causes for those failures. One can assume that there should be more peri-implantitis cases exist within those failures.

Regarding the time of implantation, 23 of the failed implants were placed immediately, while 51 of them were placed in healed sockets. It is important that none of the studies in this review had correlated implantation times with failures. In addition, the implantation times of the remaining 39 failures were unknown. However, the survival rates of all studies were known. The studies, which performed immediate implantation, had a mean survival rate of $95.69 \%$ while studies performed late implantation showed $96.29 \%$ in this review. These results are similar, which indicates that time of implantation did not have any effect on survival rates. It was reported that there isn't any statistically significant difference between immediate implantation and implant placed in healed sockets [4].

Regional differences and jaw anatomy have been discussed in terms of implant failure. Forty-one of the failed implants were placed in the maxillary bone and 31 of them were in the mandible. When the studies included in this review were investigated for failure rates according to regional differences, 5 studies suggested that there were no significant differences observed between maxillary and mandibular implants $[11,23,28,33,35]$. Three of those studies reported that there were more failures observed in maxillary implants, but there wasn't any statistically significant difference observed [25,30,32]. Only one study reported significant difference for maxillary implant failures, but in that study authors suggested 
that data on prognosis of implants showed high rates of survival can be achieved for maxillary implants [3]. The other studies in this review did not study failure rates according to regional differences. The majority of the studies in this review couldn't find any significant difference between jaws. In the literature, some studies showed significantly higher failure rates for maxillary implants due to poor bone quality $[65,66]$, while others couldn't find any difference [67]. Chrcanovic et al. reviewed the literature about dental implant failures and reported that the conclusion of maxillary implants perform not as good as mandibular ones are based mostly on old implant surfaces, such as machined implants. However, modern implant surfaces, like rough surfaces, seem to have improved outcome with the maxilla than old implants. That's probably because of the stronger implant-bone contact with modern surfaces [68]. Although a calculation cannot be made, most of the implants evaluated in this review had rough surfaces, which may relate to the view of Chrcanovic et al. [68].

Most of the longitudinal studies investigated only the survival rates of implants. That's because the evaluation of the success of implants involves more complex examination and standardization criteria. Therefore, most of the studies focused on only the survival rate of implants. There are several criteria of success classifications are being used in the literature, but there isn't any standardization exists, which makes the comparison between studies difficult. In this review, 9 of the 17 studies used analyses of success. There were four different criteria used in these studies, which were Albrektsson et al. [8], Misch et al. [7], in one study authors used their own criteria similar to Albrektsson et al. criteria [34] and in one study, authors used both Albrektsson et al. and Misch et al. criteria. This suggests that these two methods of success analyses are common methods used in studies reported implant failures in Turkey. Of the 4 studies that used only Albrektsson et al. criteria, the mean success rate was $96.14 \pm 2.21 \%$ with a mean follow-up period of $44.00 \pm 44.39$ months [27,35-37]. In accordance with this rate, of the 3 studies that used Misch et al. success criteria mean success was $95.2 \pm 2.4 \%$ with a mean follow-up period of $67.37 \pm 36.66$ months $[3,11,32]$. These rates are in accordance with the literature.

Taking into consideration the limitations of this study, one can conclude that the strongest reason for implant failure is an infection and lack of osseointegration in the Turkey Republic. In addition, immediate or late implantation has similar outcomes and the incidence of failure is increasing over time. It should be noted that firm conclusions shouldn't be made, and the results of this systematic review have to be discussed with caution because this review is unfortunately based on only a limited number of failures and the lack of data does not allow discussing implant failure in a deeper manner. Regarding the number of implants placed in this region, doubtfully, the failures are found to be very low. This is probably due to the implant surgeons are not taking relevant records, having problems with reporting data or they are not willing to report their failures. Another outcome of this review should be to encourage both the academicians and clinicians for reporting and discussing their complications so that further studies with greater numbers of subjects with more accurate data could be made.

\section{Conflict of Interest}

There are no conflicts of interest.

\section{Acknowledgements}

The authors want to thank A. Rana Konyalığlu for her contributions.

\section{References}

1. Branemark PI, Hansson BO, Adell R, Breine U, Lindstrom J, Hallen O, Ohman A. Osseointegrated implants in the treatment of the edentulous jaw. Experience from a 10-year period. Scand J Plast Reconstr Surg Suppl 1977; 16: 1-132.

2. Aykent F, Inan O, Ozyesil AG, Alptekin NO. A 1- to 12year clinical evaluation of 106 endosseous implants supporting fixed and removable prostheses. Int $\mathrm{J}$ Periodontics Restorative Dent 2007; 27: 358-367.

3. Geckili O, Bilhan H, Geckili E, Cilingir A, Mumcu E, Bural C. Evaluation of possible prognostic factors for the success, survival, and failure of dental implants. Implant Dent 2014; 23: 44-50.

4. Moraschini V, Poubel LA, Ferreira VF, Barboza Edos S. Evaluation of survival and success rates of dental implants reported in longitudinal studies with a follow-up period of at least 10 years: a systematic review. Int J Oral Maxillofac Surg 2015; 44: 377-388.

5. Stajcic Z, Stojcev Stajcic LJ, Kalanovic M, Dinic A, Divekar N, Rodic M. Removal of dental implants: review of five different techniques. Int J Oral Maxillofac Surg 2016; 45: 641-648.

6. Simonis P, Dufour T, Tenenbaum H. Long-term implant survival and success: a 10-16-year follow-up of nonsubmerged dental implants. Clin Oral Implants Res 2010; 21: 772-777.

7. Misch CE, Perel ML, Wang HL, Sammartino G, GalindoMoreno P, Trisi P, Steigmann M, Rebaudi A, Palti A, Pikos MA, Schwartz-Arad D, Choukroun J, Gutierrez-Perez JL, Marenzi G, Valavanis DK. Implant success, survival, and failure: The International Congress of Oral Implantologists (ICOI) Pisa Consensus Conference. Implant Dent 2008; 17 : 5-15.

8. Albrektsson T, Zarb G, Worthington P, Eriksson AR. The long-term efficacy of currently used dental implants: a review and proposed criteria of success. Int $\mathrm{J}$ Oral Maxillofac Implants 1986; 1: 11-25.

9. Zarb GA, Albrektsson T. Consensus report: towards optimized treatment outcomes for dental implants. J Prosthet Dent 1998; 80: 641.

10. Karoussis IK, Salvi GE, Heitz-Mayfield LJ, Bragger U, Hammerle $\mathrm{CH}$, Lang NP. Long-term implant prognosis in patients with and without a history of chronic periodontitis: 
a 10-year prospective cohort study of the ITI Dental Implant System. Clin Oral Implants Res 2003; 14: 329-339.

11. Soydan SS, Cubuk S, Oguz Y, Uckan S. Are success and survival rates of early implant placement higher than immediate implant placement? Int J Oral Maxillofac Surg 2013; 42: 511-515.

12. Esposito M, Hirsch JM, Lekholm U, Thomsen P. Biological factors contributing to failures of osseointegrated oral implants. (I). Success criteria and epidemiology. Eur J Oral Sci 1998; 106: 527-551.

13. Alsaadi G, Quirynen M, Michiles K, Teughels W, Komarek A, van Steenberghe D. Impact of local and systemic factors on the incidence of failures up to abutment connection with modified surface oral implants. J Clin Periodontol 2008; 35: 51-57.

14. Han HJ, Kim S, Han DH. Multifactorial evaluation of implant failure: a 19-year retrospective study. Int J Oral Maxillofac Implants 2014; 29: 303-310.

15. Esposito M, Hirsch JM, Lekholm U, Thomsen P. Biological factors contributing to failures of osseointegrated oral implants. (II). Etiopathogenesis. Eur J Oral Sci 1998; 106: 721-764.

16. Baqain ZH, Moqbel WY, Sawair FA. Early dental implant failure: risk factors. Br J Oral Maxillofac Surg 2012; 50: 239-243.

17. Manor Y, Oubaid S, Mardinger O, Chaushu G, Nissan J. Characteristics of early versus late implant failure: a retrospective study. J Oral Maxillofac Surg 2009; 67: 2649-2652.

18. Implantder. Implantder Dental Implant Sektor Raporu. 2015.

19. Moher D, Liberati A, Tetzlaff J, Altman DG, Group P. Preferred reporting items for systematic reviews and metaanalyses: the PRISMA statement. Int J Surg 2010; 8: 336-341.

20. Nguyen QV, Bezemer PD, Habets L, Prahl-Andersen B. A systematic review of the relationship between overjet size and traumatic dental injuries. Eur J Orthod 1999; 21: 503-515.

21. Needleman IG. A guide to systematic reviews. J Clin Periodontol 2002; 29: 6-9; discussion 37-38.

22. Higgins JP, Thompson SG, Deeks JJ, Altman DG. Measuring inconsistency in meta-analyses. BMJ 2003; 327: 557-560.

23. Ozkan Y, Ozcan M, Akoglu B, Ucankale M, Kulak-Ozkan Y. Three-year treatment outcomes with three brands of implants placed in the posterior maxilla and mandible of partially edentulous patients. J Prosthet Dent 2007; 97: 78-84.

24. Gulsahi A, Paksoy CS, Yazicioglu N, Arpak N, Kucuk NO, Terzioglu H. Assessment of bone density differences between conventional and bone-condensing techniques using dual energy x-ray absorptiometry and radiography. Oral Surg Oral Med Oral Pathol Oral Radiol Endod 2007; 104: 692-698.
25. Simsek B, Simsek S, erkmen E. The evaluation of the success rates of immediate implant placement due to the reasins for extraction GÜ Dishek Fak Derg 2003; 20: 15-20.

26. Akin H, Sari F, ozdemir H, Emre C, Tugut F, Özdemir AK. Mechanical Success and Failure of the different types of dental implants: two years follow up study. Cumhuriyet Uni Dishek Fak Derg 2009; 12: 121-124.

27. Eltas A, Uzun H, Dundar S, Arslan malkoc M. Assesement of dental implant success and patient profile: a retrospective study. J Dent Fac Ataürk Uni 2013; 21: 1-8.

28. Celebi N, Soylu E, gonen ZB, Etoz O, Kilic E, Alkan A. retrospective evaluation of dental implant success, three to five years follow up. Cumhuriyet Dent J 2013; 16: 20-24.

29. Bolukbasi N, Yeniyol S, Ozdemir T. The influence of prophylactic antibiotics on early time success of dental implants. Istanbul Univ Dis Hek Fak Derg 2013; 47: 38-46.

30. Bilhan H, Bural C, Cilingir A, Geckili O. Implant retained prosthesis, complications and implant failures: 24-month clinical result. Istanbul Univ Dis Hek Fak Derg 2012; 46: 40-46.

31. Piskin B, Gokce HS, Avsever H, Arısan V, Atac MS, K. G. prosthetic complications in implant supported fixed prosthesis: a four-year multi-center retrospective analysis. Istanbul Univ Dis Hek Fak Derg 2010; 44: 75-80.

32. Bilhan H, Mumcu E, Geckili O, Atalay B. The evaluation of the success of immediately placed single implants: a retrospective clinical study. Implant Dent 2011; 20: 215-225.

33. Atalay B, Oncu B, Emes Y, Bultan O, Aybar B, Yalcin S. Immediate implant placement without bone grafting: a retrospective study of 110 cases with 5 years of follow-up. Implant Dent 2013; 22: 360-365.

34. Guncu MB, Aslan Y, Tumer C, Guncu GN, Uysal S. Inpatient comparison of immediate and conventional loaded implants in mandibular molar sites within 12 months. Clin Oral Implants Res 2008; 19: 335-341.

35. Arisan V, Bolukbasi N, Ersanli S, Ozdemir T. Evaluation of 316 narrow diameter implants followed for 5-10 years: a clinical and radiographic retrospective study. Clin Oral Implants Res 2010; 21: 296-307.

36. Karabuda ZC, Abdel-Haq J, Arisan V. Stability, marginal bone loss and survival of standard and modified sandblasted, acid-etched implants in bilateral edentulous spaces: a prospective 15-month evaluation. Clin Oral Implants Res 2011; 22: 840-849.

37. Turkyilmaz I. A 3-year prospective clinical and radiologic analysis of early loaded maxillary dental implants supporting single-tooth crowns. Int J Prosthodont 2006; 19: 389-390.

38. Branemark PI, Adell R, Breine U, Hansson BO, Lindstrom J, Ohlsson A. Intra-osseous anchorage of dental prostheses.

I. Experimental studies. Scand J Plast Reconstr Surg 1969; 3: $81-100$.

39. Berglundh T, Persson L, Klinge B. A systematic review of the incidence of biological and technical complications in 
implant dentistry reported in prospective longitudinal studies of at least 5 years. J Clin Periodontol 2002; 29: 197-212; discussion 32-33.

40. Shrier I, Boivin JF, Steele RJ, Platt RW, Furlan A, Kakuma R, Brophy J, Rossignol M. Should meta-analyses of interventions include observational studies in addition to randomized controlled trials? A critical examination of underlying principles. Am J Epidemiol 2007; 166: 1203-1209.

41. Needleman I, Chin S, O'Brien T, Petrie A, Donos N. Systematic review of outcome measurements and reference group(s) to evaluate and compare implant success and failure. J Clin Periodontol 2012; 39: 122-132.

42. Jung RE, Pjetursson BE, Glauser R, Zembic A, Zwahlen M, Lang NP. A systematic review of the 5-year survival and complication rates of implant-supported single crowns. Clin Oral Implants Res 2008; 19: 119-130.

43. Pjetursson BE, Tan K, Lang NP, Bragger U, Egger M, Zwahlen M. A systematic review of the survival and complication rates of fixed partial dentures (FPDs) after an observation period of at least 5 years. Clin Oral Implants Res 2004; 15: 667-676.

44. Davarpanah M, Martinez H, Etienne D, Zabalegui I, Mattout P, Chiche F, Michel JF. A prospective multicenter evaluation of 1,583 $3 \mathrm{i}$ implants: 1 - to 5-year data. Int J Oral Maxillofac Implants 2002; 17: 820-828.

45. Moraschini V, Barboza E. Success of dental implants in smokers and non-smokers: a systematic review and metaanalysis. Int J Oral Maxillofac Surg 2016; 45: 205-215.

46. Zarb GA, Schmitt A. The longitudinal clinical effectiveness of osseointegrated dental implants: the Toronto study. Part III: Problems and complications encountered. J Prosthet Dent 1990; 64: 185-194.

47. Naert I, Quirynen M, van Steenberghe D, Darius P. A sixyear prosthodontic study of 509 consecutively inserted implants for the treatment of partial edentulism. J Prosthet Dent 1992; 67: 236-245.

48. Salonen MA, Oikarinen K, Virtanen K, Pernu H. Failures in the osseointegration of endosseous implants. Int $\mathrm{J}$ Oral Maxillofac Implants 1993; 8: 92-97.

49. Albrektsson T. Is surgical skill more important for clinical success than changes in implant hardware? Clin Implant Dent Relat Res 2001; 3: 174-175.

50. Renoouard f, Charrier JG. The search for the weakest link: an introduction to human factors. Paris: Ewenn Editions; 2011.

51. Lee JY, Park HJ, Kim JE, Choi YG, Kim YS, Huh JB, Shin SW. A 5-year retrospective clinical study of the Dentium implants. J Adv Prosthodont 2011; 3: 229-235.

52. el Askary AS, Meffert RM, Griffin T. Why do dental implants fail? Part I. Implant Dent 1999; 8: 173-185.

53. Lundgren S, Nystrom E, Nilson H, Gunne J, Lindhagen O. Bone grafting to the maxillary sinuses, nasal floor and anterior maxilla in the atrophic edentulous maxilla. A twostage technique. Int J Oral Maxillofac Surg 1997; 26: 428-434.
54. Ostman PO, Hellman M, Sennerby L. Direct implant loading in the edentulous maxilla using a bone densityadapted surgical protocol and primary implant stability criteria for inclusion. Clin Implant Dent Relat Res 2005; 7 : S60-S69.

55. Gunne J, Astrand P, Lindh T, Borg K, Olsson M. Toothimplant and implant supported fixed partial dentures: a 10year report. Int J Prosthodont 1999; 12: 216-221.

56. Olsson M, Gunne J, Astrand P, Borg K. Bridges supported by free-standing implants versus bridges supported by tooth and implant. A five-year prospective study. Clin Oral Implants Res 1995; 6: 114-121.

57. McDermott NE, Chuang SK, Woo VV, Dodson TB. Complications of dental implants: identification, frequency, and associated risk factors. Int J Oral Maxillofac Implants 2003; 18: 848-855.

58. Moy PK, Medina D, Shetty V, Aghaloo TL. Dental implant failure rates and associated risk factors. Int $\mathrm{J}$ Oral Maxillofac Implants 2005; 20: 569-577.

59. Lang NP, Pjetursson BE, Tan K, Bragger U, Egger M, Zwahlen M. A systematic review of the survival and complication rates of fixed partial dentures (FPDs) after an observation period of at least 5 years. II. Combined tooth-implant-supported FPDs. Clin Oral Implants Res 2004; 15 : 643-653.

60. Balshi TJ. An analysis and management of fractured implants: a clinical report. Int J Oral Maxillofac Implants 1996; 11: 660-666.

61. Takeshita F, Suetsugu T, Higuchi Y, Oishi M. Histologic study of failed hollow implants. Int J Oral Maxillofac Implants 1996; 11: 245-250.

62. Chappuis V, Buser R, Bragger U, Bornstein MM, Salvi GE, Buser D. Long-term outcomes of dental implants with a titanium plasma-sprayed surface: a 20-year prospective case series study in partially edentulous patients. Clin Implant Dent Relat Res 2013; 15: 780-790.

63. Chrcanovic BR. A History of Periodontitis Suggests a Higher Risk for Implant Loss. J Evid Based Dent Pract 2015; 15: 185-186.

64. Al-Sabbagh M, Bhavsar I. Key local and surgical factors related to implant failure. Dent Clin North Am 2015; 59: $1-23$.

65. Devlin H, Horner K, Ledgerton D. A comparison of maxillary and mandibular bone mineral densities. J Prosthet Dent 1998; 79: 323-327.

66. Martinez H, Davarpanah M, Missika P, Celletti R, Lazzara R. Optimal implant stabilization in low density bone. Clin Oral Implants Res 2001; 12: 423-432.

67. Naert I, Koutsikakis G, Quirynen M, Duyck J, van Steenberghe D, Jacobs R. Biologic outcome of implantsupported restorations in the treatment of partial edentulism. Part 2: a longitudinal radiographic study. Clin Oral Implants Res 2002; 13: 390-395.

68. Chrcanovic BR, Albrektsson T, Wennerberg A. Reasons for failures of oral implants. J Oral Rehabil 2014; 41: 443-476. 
What is the survival rate of dental implants in Turkey? A systematic review

\section{*Correspondence to}

Fatih CABBAR

Assistant Professor

Department of Oral and Maxillofacial Surgery
Faculty of Dentistry

University of Yeditepe

Turkey

Email: fcabbar@gmail.com 